\title{
Character and Circumstances
}

\begin{abstract}
In the tradition of virtue ethics, moral wrongdoing at work and elsewhere is explained in terms of weakness of character. In this view, a person who prioritizes self-interest over client interest and engages in other kinds of moral transgressions exposes him or herself to be someone of dubious moral character. A response within this tradition to ethical scandals in business has been to call for authentic leadership exercised by individuals who consistently embody firmness of character. Experimental studies in social and moral psychology have put the virtue of ethical assumptions regarding moral wrongdoing under pressure and have suggested that circumstances affect decision-making and conduct to a high degree. An empirically oriented ethics in organizations should take into account that character and circumstances both affect conduct. When morally questionable behavior in professions and organizations is exposed, it is not enough to simply sack the culprits and replace them with morally clean and authentic individuals. Earmarking leadership for morally strong and authentic individuals may be an outdated construct. Circumstances, often in the shape of incentives and decision-making structures, are significant causes of wrongdoing, and revising them appears to be the most promising measure to encourage responsible and fair decision-making within organizations.
\end{abstract}

Keywords Character • Circumstances • Authentic leadership • Honesty

(C) The Author(s) 2019

$\varnothing$. Kvalnes, Moral Reasoning at Work, https://doi.org/10.1007/978-3-030-15191-1_12 
All members of an organization frequently face decisions, from real to false moral dilemmas. In some cases, it can be a struggle to decide what is the morally right or the least morally wrong option, as all available options involve a sacrifice of considerable moral importance. In other cases, it is obvious to the decision-maker what he or she should do from a moral point of view, but it is tempting to do act in another way so as to enhance self-interest in some way. The financial advisor needs another big sale before Monday's meeting with her supervisor, and the client who just walked in the door is both rich from a new inheritance and blind to economic realities.

As a client, customer, or patient, you hope that professionals provide advice based on what is in your best interest, and not necessarily in the professional's own interest. In this chapter, I explore two alternative approaches to what that hope of experiencing responsible conduct in organizations can build upon. The first approach maintains that the foundation for such conduct is the character of decision-makers: Professionals and their leaders need to consistently embody the principles of integrity, responsibility, compassion, and forgiveness to behave decently at work (Kiel, 2015). When a person fails or struggles to live in accordance with these principles, it is a sign of personal moral weakness. Such a person must work on his or her moral constitution or, alternatively, find work elsewhere in a position in which his or her personal moral shortcomings cannot lead to serious moral wrongdoing. The second approach claims that people should be less concerned about character and more concerned about circumstances. A range of studies in social psychology and behavioral economics document that aspects of the situation have a strong impact on whether a person engages in moral misconduct (Ariely, 2012; Baron, 1997; Doris, 2002; Isen, 1987; Mazar \& Ariely, 2010). The social environment and events within it affect decision-making and conduct to a stronger degree than what the character perspective typically acknowledges.

Virtue ethics has identified the central, individual factor concerning ethical decision-making to be a person's moral character or set of stable and reliable virtues. A person of strong character can withstand temptations to engage in wrongdoing, while a person of weak character is unreliable in this sense. In the aftermath of recent scandals of corporate moral wrongdoing, virtue ethics has influenced significant developments in organizational ethics and leadership studies. Concerned scholars and practitioners have responded to the widespread examples of immoral behavior 
among leaders and professionals by promoting ideals of authentic leadership (Avolio \& Gardner, 2005; Gardner, Cogliser, Davis, \& Dickens, 2011).

One basic assumption in this research field is that great leadership requires great character (Kiel, 2015). In this view, leaders need to consistently embody virtuous character traits in their everyday dealings with employees and other stakeholders. By doing so, they can serve as good role models within their organizations and contribute to normalizing responsible workplace behavior. Kiel (2015) suggests that leaders of morally strong character generate more income for their companies. However, this causal relationship may go the other way as well. The study in question documents that companies with leaders who are perceived to be morally strong outperform those with leaders who are perceived to be morally weak; however, it may be easier to embody virtuous character traits when you are in charge of a successful company rather than a struggling one in which you can have economic incentives to cut corners.

Authentic leadership is another concept used to identify what organizations should look for when recruiting leaders to top positions (Avolio \& Gardner, 2005; Walumbwa, Avolio, Gardner, Wernsing, \& Peterson, 2008). Authentic leaders have been defined as "those who are deeply aware of how they think and behave and are perceived by others as being aware of their own and others' values/moral perspectives, knowledge, and strengths; aware of the context in which they operate; and who are confident, hopeful, optimistic, resilient, and of high moral character" (Avolio, Luthans, \& Walumbwa, 2004, p. 4).

I have previously discussed authentic leadership in the context of how leaders respond to the dilemma of providing a reference for an employee who has caused conflict within the organization, in which lying or being economical with the truth can strengthen the likelihood that the employee will get a new job (Kvalnes, 2014). This chapter expands on the reflections in that study, which defined the authentic person as someone with a high degree of self-awareness who acts in accordance with his or her true self by expressing what he or she genuinely thinks and believes. Authenticity in this sense can be linked to Aristotelian virtue ethics with its emphasis on self-realization and well-being-eudaemonia-as a state of happiness where the person acts and lives in accordance with who he or she really is. The central component of eudaemonia is the exercise of virtues. Only people who possess virtues, like courage, honesty, and loyalty, will truly flourish and be happy in the eudaemonian sense. The virtuous person has 
a particular mind-set, a deeply entrenched set of dispositions to act and respond to situations in a particular way that is guided by virtue.

A truly honest leader does not lie in the reference situation, even though he or she has strong, self-interested reasons to do so. When this leader tells the truth, it is not out of blind habit, because it is the best way to make a good impression on others, or out of fear of the consequences of being caught in a lie. Rather, this leader believes that truth is a particularly strong-if not always overriding - reason for honesty. Although he or she understands that a lie may increase the likelihood of unloading a problem employee, virtue overrides such reasoning. Similarly, a virtuous financial advisor considers "this is the impartial and honest advice for my client" to be a particularly strong reason for providing that particular advice to the client, overriding self-interest and other considerations. The smartest action that the client can take is to reduce personal debt, so that is what the virtuous financial advisor suggests, even if it is not necessarily a profitable option for the advisor or for his or her employer.

Virtue can come in degrees. Aristotle distinguished between full virtue, in which an honest person tells the truth without experiencing any trace of a contrary temptation to lie, and less than full virtue, in which the person telling the truth has to overcome a desire to do otherwise (Aristotle, 2011). The latter is also an honest person as long as the reasons for telling the truth are not opportunistic but based on a conviction that telling the truth is the morally right option. Immanuel Kant considered the act of overcoming one's desires so as to behave in the right way as more worthy of praise than acts in which there is full harmony between reason and inclination and in which the decision-maker behaves correctly and without inner struggle (Kant, 1998 [1785]).

A virtue in the Aristotelian sense has four elements, in that it affects a person's intellectual, emotional, motivational, and behavioral responses to a particular situation (Alzola, 2015; Aristotle, 2011). When faced with an opportunity to get rid of a quarrelsome employee by lying, the virtuous leader is capable of understanding that it would be wrong to lie (intellectual element), is not tempted to do so (emotional element), stands firm against any pressure to deviate from this understanding (motivational element), and responds in the appropriate manner when the situation arises (behavioral element). The behavioral element builds on the other three elements in guiding the virtuous leader's decision-making.

Various accounts of authentic leadership share with virtue ethics an assumption about firmness of character. How will the leader respond to an 
opportunity to earn quick money by acting against his or her moral convictions? The standard answer from virtue ethics is that it depends on the stability and robustness of leader's character. If he or she is an authentic leader, or so the contributors to this field of research argue, internal moral standards will guide his or her decisions and conduct. The intellectual, emotional, motivational, and behavioral elements of virtue steer the decision-maker in the morally right direction.

Empirical research in social psychology and behavioral economics indicates that the character-oriented approach has underestimated how circumstances affect decision-making. Situational circumstances often appear to override character in affecting a person's response to a moral challenge. A range of experiments has demonstrated that circumstances influence what people actually do when they face a moral test. One study demonstrated that helping behavior toward strangers in a supermarket, in the form of retrieving a dropped pen or providing change for a coin, increased when the decision-makers were exposed to pleasant fragrances (Baron, 1997). A range of studies have indicated that honesty levels can be manipulated by making changes to the circumstances (Ariely, 2012). For example, students who have recently been reminded of the Ten Commandments are much less likely to cheat than those who have not (Mazar \& Ariely, 2010). Doris (2002) has outlined how these and similar studies indicate the need for more empirically informed ethics that give appropriate weight to what empirical research has shown regarding the influence of circumstances on decision-making.

From an organizational perspective, one of the most optimistic tendencies in the research is that moral reminders can serve to encourage ethical behavior. That is the conclusion Mazar and Ariely (2010) drew from their study of honesty among students. Similarly, Desai and Kouchaki (2017) explored how exposure to what they call moral symbols can serve as "a necklace of garlic" against unethical behavior in organizations. In traditional horror stories, garlic serves to keep vampires at a distance. The authors set out to determine whether encounters with symbols that are designed to activate moral awareness, such as a cross, quotes, icons, and photos of moral prototypes, like Mahatma Gandhi, can influence decisionmaking. More specifically, they were interested in whether subordinates can use moral symbols to discourage their superiors from asking them to perform unethical tasks. Their bottom-up perspective deviates from most other studies of superior-subordinate relationships, which are top-down and tend to focus on how superiors affect the decision-making of 
subordinates. Their main findings from five laboratory studies and one organizational survey study is that exposure to moral symbols dissuades superiors both from engaging in unethical behaviors themselves and asking their subordinates to engage in unethical behavior (Desai \& Kouchaki, 2017).

Circumstances seem to have a more profound influence on conduct and decision-making than character approaches typically acknowledge, and moral symbols can serve as activate considerations about right and wrong. Some of the participants in my ethics training sessions have reported that they have taken photocopies of the Navigation Wheel and distributed them among colleagues. They use it as a moral symbol, an activator of moral awareness and concerns, in line with the definition of Desai and Kouchaki (2017). It seems that such an initiative can serve a positive purpose beyond being a tool for ethical analysis. Seeing the Navigation Wheel on one's desk or on the wall in the office may serve as a modest reminder of the normative dimensions of decision-making and, as such, be a circumstantial component in a work environment where employees are expected to behave responsibly. The cognitive purpose of the Navigation Wheel and similar tools is to assist analysis of complex situations; its emotional and motivational purposes can be to serve as a moral reminder and as an activator.

In a study of the financial crisis in Iceland, Nordal and I reflected on the consequences of adapting a character or a circumstance approach to moral wrongdoing (Kvalnes \& Nordal, 2018). In that country, a character approach has dominated the responses to the misbehavior that produced the crisis, leading to an apparently permanent sidelining of people who made moral mistakes and misbehaved in the processes leading up to it. A handful of bankers and politicians have been labeled as permanently untrustworthy due to their involvement in questionable behavior. With this approach, the dominant remedy against further wrongdoing is to dismiss those individuals and replace them with new ones while keeping the system more or less intact. A circumstance approach would suggest that it is crucial to explore how organizational procedures and structures affected the decision-making that led to the financial crisis. Simply substituting the people who were responsible for the collapse and only making cosmetic systemic changes is not likely to prevent further trouble in the Icelandic financial sector (Kvalnes, 2017; Kvalnes \& Nordal, 2018).

Tensions between character and circumstance approaches to wrongdoing have also been a featured in criminology. Criminals have traditionally 
been identified as "insane, inadequate, immoral, impulsive, egocentric" despite a lack of evidence to support such assumptions (Coleman, 1989, p. 200). The criminologists Sykes and Matza (1957) developed an alternative model for understanding criminal activities. Their main hypothesis was that criminals were committed to more or less the same moral standards and norms as their fellow noncriminal citizens. The difference was that the criminals had managed to convince themselves that breaking the law was acceptable through processes of what the authors called moral neutralization.

In the next chapter, I argue that organizational ethics can benefit from adopting a similar way of understanding wrongdoing. By doing so, the field can move beyond the call for authentic leadership and firm character by providing supplementary emphasis on how people can shape organizational cultures to be alert against attempts of moral neutralization.

\section{REFERENCES}

Alzola, M. (2015). Virtuous persons and virtuous actions in business ethics and organizational research. Business Ethics Quarterly, 25(3), 287-318.

Ariely, D. (2012). The (honest) truth about dishonesty. New York: Harper Collins. Aristotle. (2011). Nicomachean ethics (R. C. Bartlett \& S. D. Collins, Trans.). Chicago: University of Chicago Press.

Avolio, B. J., \& Gardner, W. L. (2005). Authentic leadership development: Getting to the root of positive forms of leadership. The Leadership Quarterly, $16(3), 315-338$.

Avolio, B. J., Luthans, F., \& Walumbwa, F. O. (2004). Authentic leadership: Theory building for veritable sustained performance. Working paper: Gallup Leadership Institute. University of Nebraska-Lincoln.

Baron, R. A. (1997). The sweet smell of ... helping: Effects of pleasant ambient fragrance on prosocial behavior in shopping malls. Personality and Social Psychology Bulletin, 23(5), 498-503.

Coleman, J. W. (1989). The criminal elite: Understanding white-collar crime. New York: St. Martin's Press.

Desai, S. D., \& Kouchaki, M. (2017). Moral symbols: A necklace of garlic against unethical requests. Academy of Management Journal, 60(1), 7-28.

Doris, J. M. (2002). Lack of character: Personality and moral behavior. New York: Cambridge University Press.

Gardner, W. L., Cogliser, C. C., Davis, K. M., \& Dickens, M. P. (2011). Authentic leadership: A review of the literature and research agenda. The Leadership Quarterly, 22(6), 1120-1145. 
Isen, A. M. (1987). Positive affect, cognitive processes, and social behavior. In L. Berkowitz (Ed.), Advances in experimental social psychology (Vol. 20, pp. 203-253). Elsevier.

Kant, I. (1998 [1785]). Groundwork of the metaphysics of morals (M. Gregor, Ed.). New York: Cambridge University Press.

Kiel, F. (2015). Return on character: The real reason leaders and their companies win. Harvard Business Review Press.

Kvalnes, Ø. (2014). Leadership and moral neutralisation. Leadership, $10(4), 456-470$.

Kvalnes, Ф. (2017). Fallibility at work: Rethinking excellence and error in organizations. London: Palgrave Macmillan.

Kvalnes, Ø., \& Nordal, S. (2018). Normalization of questionable behavior: An ethical root of the financial crisis in Iceland. Journal of Business Ethics, 1-15.

Mazar, N., \& Ariely, D. (2010). Sequential influences on dishonest behavior. Advances in Consumer Research, 37, 143-145.

Sykes, G. M., \& Matza, D. (1957). Techniques of neutralization: A theory of delinquency. American Sociological Review, 22(6), 664-670.

Walumbwa, F. O., Avolio, B. J., Gardner, W. L., Wernsing, T. S., \& Peterson, S. J. (2008). Authentic leadership: Development and validation of a theory-based measure. Journal of Management, 34(1), 89-126.

Open Access This chapter is licensed under the terms of the Creative Commons Attribution 4.0 International License (http://creativecommons.org/licenses/ by $/ 4.0 /$ ), which permits use, sharing, adaptation, distribution and reproduction in any medium or format, as long as you give appropriate credit to the original author(s) and the source, provide a link to the Creative Commons licence and indicate if changes were made.

The images or other third party material in this chapter are included in the chapter's Creative Commons licence, unless indicated otherwise in a credit line to the material. If material is not included in the chapter's Creative Commons licence and your intended use is not permitted by statutory regulation or exceeds the permitted use, you will need to obtain permission directly from the copyright holder.

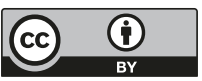

